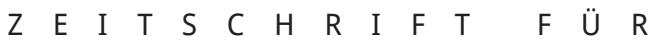

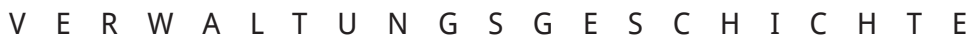

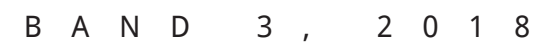

S E I T

D O I : $10.2478 / \mathrm{ADH}$ I- $2018-0037$

\title{
Litigious Paranoia: Sense of Justice, Bureaucracy, and Media
}

\author{
RUPERT GADERER
}

\section{Sense of Justice}

'Quarrelers`, according to the president of the German Federal Administrative Court between 1958 and 1969, should not be judged with the same standards as a common citizen. ${ }^{1}$ People who take excessive legal action and file countless complaints are - in his opinion usually sick. Still today forensic psychiatry assumes that such querulous behavior is the result of a pathological increase in an emotion, or more specifically a pathological increase in a person's sense of justice ${ }^{2}{ }^{2}$ Litigious paranoia is said to be an obsessive endeavor to realize justice and a concept of justice - the origin of which can be found in the human psyche. It is precisely the legal system and psychiatry that, in the history of litigious paranoia or paranoia querulans, have dealt extensively with this behavior, after all they, as the observers of society and the authorities for pronouncing judgments, were and are most affected by it. This assessment is still confirmed by administrative employees, physicians, and lawyers when they are confronted every day with angry emotions in numerous letters, emails, or personal conversations: fury, contempt, hate, pride, but also fear, suffering, and hope.

In the last few years, investigations have been carried out on the relationship between emotions and justice in connection with the Anglo-American law-andemotion debate, ${ }^{3}$ which in German-speaking countries has been discussed for the most part under the concept 'Rechtsgefühl (sense of justice). In Germany, most of the contributions have come from the field slegal sociology and in recent years research has been carried out in the cultural and literary sciences. ${ }^{4}$ The present mediahistorical investigation of litigious paranoia takes these results into consideration and emphasizes three aspects in particular. First, the question of the historicity of emotions is pursued, the temporally and spatially dependent power derived from emotions to take action and the social contextualization of emotions. ${ }^{5}$ Second, those media are shifted from the periphery to the center of cognitive interest which are brought into play to transfer the fury, the hate, but also the desperation and the suffering to the bureaucratic situations, to store and erase them. Third, those power relationships will be dealt with that come into play in the history of litigious paranoia as a result of emotions activated by the media. One focus in this paper is the technologies of power to depart from the notion that the impact of power results first of all from rules, laws, and prohibitions. ${ }^{6}$ If one summarizes these three aspects, one can say 
that the goal of this paper was to find, using a media history of litigious paranoia, the legal and psychiatric power relationships and to identify the different recording methods which play a role in documenting the knowledge of querulous behavior as an excessive emotion.

Without the systematic consideration of these elements - which is the assertion of this paper - the emotions that play a role in querulous behavior cannot be recognized and described in all their complexity. However, the methodological decision behind this comes with consequences: The emphasis is not placed on the subjects who have been made outcasts, as the president of the Administrative Court and numerous psychiatric and legal investigations have done. Rather, it is the techniques, actions, and implementations that are investigated, which convert a behavior and its respective emotions into relationships on which commentaries are possible. It is not a matter of who, when, and where a person was labeled querulous - not an empirical list of names, dates, places, or offenses. The stakes in this media-historical approach consist of placing the emphasis on operations and cultural techniques, as they rely on symbols, persons, and material artifacts, interchange them, and are responsible for investigating and punishing someone as a querulous person. Of course, a media history of the excessive sense of justice deals with people who are labeled querulous - that goes without saying. However, one dare not fall into the trap of overlooking the cultural tools and media which are hidden behind litigious paranoia.

\section{The sCreation` of Querulanten}

Before querulency was investigated as a form of insanity, it was a bureaucratic problem. Towards the end of the 18th century, the bureaucratic power of Prussia, effected by the General Court Code for the Prussian States of 6 July 1793 (AGO: Allgemeine Gerichtsordnung für die Preußischen Staaten), created the modern querulous figure by imposing controlled forms of legal writing on individuals. In this codified text on natural law, in which the rules for plaintiffs and legal justice in court cases were stipulated, the quarreler was created as a specific
Those parties that do not submit to the prescribed order, but rather discommode either their colleagues and their superiors with apparently unfounded and unlawful complaints against better science and convictions; or after they have been shown to be in the wrong, nonetheless continue with their suits, and by means of repeated inappropriate petitioning, to attempt to force and assert something, in violation of law and order; or finally undertake to bother the Justice Department, or the person of His Majesty the King with false and inaccurate presentations of their demands, or with untrue and fictitious allegations and insults of their colleagues and the courts shall be seen as malicious or spiteful quarrelers (German, Querulanten), shall be tried, and their sentence shall be legally binding ( $§ 30$ AGO, Part III, 1).

Knowledge about "malicious or spiteful quarrelers" (§ 30 AGO, Part III, 1) came from social control, bureaucratic surveillance, and legal discipline. A plaintiff who carried the threat of acting querulously, either at present or in the future, was understood to be a disturbance by the bureaucratic power. Quarrelers were, in the regulations and codes of the Prussian administration, conceived of as a disturbance in the complex bureaucratic procedures because they filed too many complaints. At a particular time and in precisely designated spaces, the quarreler was thus observed, examined, and closely watched by the Prussian administrative apparatus, both as a specific type of plaintiff and as a writer. Individuals who were investigated by the bureaucratic power brought attention to themselves by their repeated infractions. The plaintiffs caused the mountains of records to continue to grow and overtaxed the elementary forms of action for filing records in Prussia. ${ }^{7}$

The creation of quarrelers can be described as an effect of the media, or more specifically, we should call this an effect of the supplication system of the 18th century. The ssupplication system was the institutionalized means of appealing to governmental authorities in the form of requests, complaints, or lawsuits. In the 18th century, the term supplik referred to a petition or a letter of grievance complaining about an injustice suffered by the writer. ${ }^{8}$ People sent 'Suppliken to the sovereign authorities to complain about infringements of the law. At that time, 
petitioners were given a channel for bringing their assumed injustice to the attention of the sovereign authorities by means of the paper medium the sSupplik, and the bureaucratic procedure sSupplikations. In the regulations and codes of the Prussian administration, the quarrelers were conceived of as a disturbance in the complex bureaucratic process around 1800 because they filed too many petitions. Besides this administrative connection, it should be noted that a specific relationship developed between justice and emotions in the late 18th century. The concept of a sense of justice arose in connection with aesthetic, anthropological, and moral-philosophical discussions in the late 18th century. In the Age of Enlightenment, they led to the affirmation of epistemological characteristics of these emotions. Distinguishing between just and unjust was, as conceived at that time, a process involving reason but also emotional feelings. The sense of justice was considered a subjective seismograph for determining breaches of the law, but it was also considered a feeling that in an excessive manifestation constituted a danger. This was connected with the political and social changes during the transition period around 1800, in which the relationship between the state and its citizens was restructured. The debates on the rights and obligations of the enlightened citizen concentrated on placing the accountability and control of the administration of justice as well as of the implementation of justice within the bureaucracy on the people. The governmental concern in bureaucratic administration focused on the appropriate sense of justice, such that querulous behavior was described as an excessive sense of justice.

In this context, the case of the miller Mr. Arnold is clearly the best known in German legal history, and the texts written by millers were the best known querulous medium around 1800. During the court case and the supplikation procedure, the authorities found the miller and his wife guilty of a dangerous distortion and excessive sense of justice. The couple was arrested and imprisoned as quarrelers because of their repeated appeals to Friedrich II. ${ }^{9}$ Looking more closely at the petitioning of the millers is worthwhile here. What sticks out in these media of complaints is a writing style which is driven by a rhetoric of submission, submissiveness, and subordination. The petitions are presented in the petitioners by a bureaucratic power over writing. In their `Suppliken`, the millers pleaded with terms such as »innbrünstigst « (most fiercely), »ächzend « (groaningly), "flehend « (imploringly), "weinend « (with crying), and "seufzend" (with sighing) to arouse the attention of their sovereign. ${ }^{10}$ The millers summoned the sovereign and the sSupplik summoned the petitioners to reveal their own emotions which resulted from unjust attacks from the officials who pronounced judgment on the Arnolds and rejected their petitions.

The pleas and rituals of such texts were not subject to any antagonistic order; they were not as contradictory or collisional as has been assumed at times. ${ }^{11}$ Much more so, it can be claimed that the complaints served the ritual, as petitions are ritualized cries and are subject to a bureaucratic management of emotions. The petitioning language distances itself over and over again from linguistic regimentation when scenes of suffering are drastically depicted and the petition collides with the administrative style (Latin: stilus curiae). This is connected to the overemotionalization of the language which, even if it submits to the power over writing and adapts mimetically to the demands on writing, repeatedly departs from the dictated form.

The emphatic language that appeals insistently and energetically to the sovereign refers not only to the complaint about the inflicted suffering but also to the protective function of the sovereign as defined in the social contract. Such sentences and legal demands could be drafted, because someone was aware on the one hand of the rights to his or her rights. On the other hand, the sSupplik « was the medium onto which socially contractual ideas were projected, which determined free access for citizens to the administration of justice and to the sovereign as the last (and highest) authority. At the same time, this example makes clear that within the Prussian system of power the system of supplication was not solely established so that the subjects could obtain their rights. It was also established as a declaration of self which called upon the citizens to study their emotions and to write down an account of what they felt to be an injustice. Such `Suppliken « were a part of that bureaucratic fabric of writing that pervaded the behavior and expression of the people in Prussia to register their lives and make them communicable. 
The bureaucratic discussions about quarrelers were coupled with a massive increase in and further development of the administrative departments in Prussia. ${ }^{12}$ At the height of this transformation, which was its conclusion at the same time, the servant of a ruler became the servant of the state, the territorial royal state became the bureaucratic institutionalized state, and the persistent plaintiff or petitioner became the quarreler. With this possibility of regimenting individuals, of penalizing them bodily, morally, and socially because of their repeated petitions, in other words, with these legal practices, which were extensively inscribed in social, political, and cultural networks towards the end of the 18th century, the modern history of the quarrelers began. Persons identified as quarrelers were sentenced to jail, prison, or penitentiary terms that varied in length from 14 days to six months, depending on the grounds for the petition, the proven level of >malice`, and the spersistency، of the plaintiff or petitioner.

Friedrich Kittler showed in his study "Aufschreibesysteme 1800/1900" (Discourse Networks 1800/1900) that, during the process of the reformation of the Prussian school system, specific subjects to authority were created..$^{13}$ By means of the social control of the schools, the institutionalized administration of correspondence, and guidelines for reading instruction, the subjects were turned into citizens and later into civil servants. With the measures introduced by the Prussian school reform at the end of the 18th century, education took on a state mission. To detect such an interwoven disposition of institutions, media, and practices, Friedrich Kittler made an eminent observation: Kittler argued that the civil service for men entered a new phase at this time and institutionalized the citizens as civil servants. The state became an institution of education and the citizens were brought up to be civil servants. The central argument of "Discourse Networks $1800 / 1900$ « is that around 1800 universal civil servants were created for the first time.

What is formulated here against the background of the pedagogical, bureaucratic, and also literary discourse of the Goethe era is a media and cultural history of the creation of subjects, and thus not a history of the invention of technical equipment, instruments, or processes. Rather it is the story about how people for Kittler's theoretical framework for the screation of subjects is Michel Foucault's "The Order of Things" and his well-known appeal for waking up out of an "anthropological sleep «. ${ }^{14}$ However, Kittler expanded on Foucault's starting point by reformulating it more technically and more materialistically. Correspondingly, it became possible for him to decipher the sself ^ from a media-historical and media-philological perspective as a conglomerate of reading and writing, in other words, to make the cultural skills reading and writing the focal point that was fundamental for the Prussian school reforms of the 18th century. The Prussian school reforms, taken under the conditions of the print media monopoly, were the prerequisite for extremely effective control of the social system.

This step in the detection process also results from an analysis of the regulation that schools were interpreted as one of the institutions of the state ( $\$ 1$ ALR 1794, II. Theil, 12 [§ 1, 2nd part, 12 of the General State Laws for the Prussian States of 1794]) and as such the principle of self-government was installed in them. Accordingly, following Friedrich Kittler's line of thinking, the media and legal scholar Cornelia Vismann, for one, when she wanted to show in "Files: Law and Media Technology“ which media power structures created citizens out of subjects around 1800, argued that subjects were created because they were given the possibility of administering themselves; in the recordkeeping Prussian nation, each citizen was his own civil servant and the strict delineation between official and private records disappeared. ${ }^{15}$ For Vismann's mediascientific legal investigation, the practical realization of the principle of self-government is one reason for the ceaseless proliferation of records in Prussia. As a result of the self-governing administration in Prussia, reports were written on reports, ministries reported about ministries, and resolutions were passed on resolutions. Even though the bureaucracy attempted to reduce the proliferation, the mountains of record files only grew to a maximum as a result of the reduction techniques and literacy training in the schools. Using this perspective of the cultural techniques in the legal system, Vismann showed that the record files represented a legal medium and that by means of these files authoritative and administrative activities could be substantiated or made observable. According to Vismann, the files do not 
merely shape the truth and the state but shape the third main entity in law just as much: as a media technique, they form the subject. ${ }^{16}$

First of all, we can say that the epochal threshold around 1800 was described as a time of pedagogical and bureaucratic legal reforms. Media and cultural techniques - beginning with reading and writing exercises using glasses and quill pens, then the introduction of school textbooks, followed by filing systems - can be seen as essential for establishing a constitution of the subject. The citizens were brought up to become officials, bureaucratic media massively influenced the everyday life of individuals, and this led to a convergence of administrative processes and literature. This cursory media-historical identification of the bureaucracy and its media is crucial because following this we can recognize that besides the transformation of citizens into civil service officials a parallel history can be developed. The history of the creation of the quarreler is a parallel history to the creation of the Prussian civil servant. The excessive petitioners were such a big administrative problem at that time, because they were a creation of the bureaucracy and a shadow of it. The quarreler was nothing more than a disturbance immanent to the system which was an effect of the media techniques of the bureaucracy.

Here, it can be seen that the sSuppliken s that could be considered querulous writing were documents of the self-perception of people, produced either voluntarily or wrested from them: documents that provided information about familial, political, social, and cultural circumstances in individual systems, at certain times, and in certain locations. The sSupplikı as a writing technology formed a link between the private and administrative sectors and made people and their emotions more transparent than they had been before the intensive expansion of the supplication system. The things that the petitioners wrote in their letters demonstrated, on the one hand, their everyday fear of deteriorating social status, of a loss of property, and of a social and moral decline. On the other hand, these sSuppliken assured them of the certainty that they could demand and receive justice. The sSuppliken that time document a reflection on emotions and were

\section{The Psycho-Pathologization of Complaints}

Not only was querulous behavior classified as an administrative disturbance by criminal courts, surveillance, educational, and investigative institutions were also established to keep it in check. A major portion of the judicial assistance was provided by psychiatry; ${ }^{17}$ however, other disciplines appeared during the course of the 19th century, such as legal psychology and legal anthropology, which took on the task of elucidating querulous people by investigating their emotions. Starting in the 1850s, physicians and lawyers were chosen as experts and authorities for analyzing knowledge about the sense of justice associated with querulous behavior. They were charged with appraising and sentencing querulous people. ${ }^{18}$

The physicians and lawyers did not accept, as has sometimes been assumed, ${ }^{19}$ the administrative knowledge about querulous behavior from the 18th century without question to diagnose it as a disease. They knew exactly from which aspects of bureaucratic knowledge they could continue and which views had to be further developed and expanded to classify such behavior as an illness. The question of truth, that is, the question whether someone had acted rightly or wrongly, was of no consequence for the majority of legal psychiatric and legal psychological investigations at that time. Rather the research interest was centered on how a legal conflict affected human emotions and in turn affected actions and thought. It was not important whether the petitions made just or unjust claims. Relevant was only how the people petitioned. In this connection, the opinion was increasingly voiced that querulous behavior could be described by observing and investigating the emotions. In the 1850s, quite prominent efforts began to define querulency as an abnormal sense of justice.

If one gains an overview of the state of the research, it will soon become clear that the knowledge about the sense of justice was a profoundly uncertain knowledge and the concept was a declaration of war for some: There were and there are still today significant differences in the definitions of the sense of justice in legal sociology, ${ }^{20}$ legal philosophy, ${ }^{21}$ legal psychology, ${ }^{22}$ legal history, ${ }^{23}$ and cultural or literary studies. ${ }^{24}$ Repeatedly, it has 
been observed that there was no clearly delimitable concept for the sense of justice and that quite different topics were discussed under this heading. ${ }^{25}$ There have even been radical demands to abolish the concept in investigations on the genesis of moral and legal judgments. ${ }^{26}$

From a media-historical perspective, it can, however, be asserted that the discussions on the sense of justice at the end of the 18th century followed a psychologized and moralized definition of this concept - assuming an individually characterized emotion and inner feelings. ${ }^{27}$ At that time, the concept sense of justice was set semantically in criminal and penal writing. A person who was in the right, according to the ever-growing legal philosophical view, had a sense of what was just. The sensing of justice became the basis at that time for the perception of one's own legal existence. It did not merely refer to a moment of self-determination but also moments of threats or risks to a similar extent. This is most obvious in the legal, medical, and literary accounts starting at the end of the 18th century, in which warnings were voiced against a dangerous deformation of the sense of justice. No matter how positive the connotation of the sense of justice was in the natural law movement or among some codifiers - the drawbacks were pointed out for good reasons. The alarms arising from these emotional drawbacks crystallized in the figure of the querulous person. This figure was described in various disciplines as having an abnormal sense of justice.

No later than the 1850s, those persons who were considered to have an exaggerated sense of justice were not just physically punished by the legal-bureaucratic power. Increasingly, psychiatric disciplining was employed for the deviant petitioners. The forensic specialist Johann Ludwig Casper in his "A handbook of the practice of forensic medicine, based upon personal experience« (London: 1861) (Practisches Handbuch der gerichtlichen Medizin [1858]) was perhaps the first to report about a frequently occurring illness which resulted from a supposed infringement of the awareness of justice among individual plaintiffs whose sense of justice could grow into an insane legal dogmatism. ${ }^{28}$ It is hardly surprising that Casper, who first placed querulency in the alchemist's kitchen of psychiatry, was taken to be the founding father of modern forensic medicine, where the quarreler was first observed, namely in Prussia. Later, in the last quarter of the 19th century, psychiatry took an enhanced hold of querulency in the process of establishing itself academically by creating professorships and expanding psychiatric asylums in Germany. The intensive investigation of querulency as a mental illness came at the same time as the extensive institutional expansion of the discipline psychiatry in Germany, starting in the 1870 s. $^{29}$ The last third of the 19th century, which is considered the heyday of psychiatric asylums and psychiatry, was also the heyday of the specialist and public discussion of so-called litigious paranoia (paranoider Querulantenwahnsinn), which was diagnosed by psychiatrists as an abnormality in the patient's sense of justice.

The question as to what caused litigious paranoia was answered differently by the psychiatrists. It was not just the medical files and court records which snowballed; the designations for the illness and its causes also increased drastically. They were first listed in files and later published in studies: monomania, ${ }^{30}$ a fixed idea ${ }^{31}$ or fixed delusional idea, ${ }^{32}$ an affected reaction, abnormal organization of the brain,,33 a subclassification of chronic paranoia, and psychogenic psychosis were terms used to try to describe querulous behavior. Divergent opinions about the kind of illness and in some instances heated discussions on the different scholarly opinions determined the uncertain psychiatric knowledge about litigious paranoia. Jacques Lacan, who categorized and investigated the different views on quarreler insanity in his 1932 dissertation "On Paranoiac Psychosis in its Relations to the Personality“ (De la Psychose paranoïaque dans ses rapports avec la personnalité suivi de Premiers écrits sur la paranoia) ironically commented that - as a result of the proliferating volume of material to be investigated - his doctoral advisor wrote to Lacan that he felt for him if he had actually read everything. ${ }^{34}$

A certain fascination emerges from these psychiatric studies, which to a large part resulted from the confusion about the scientific terminology. About 200 publications, ranging from extensive monographs, papers in medical journals, or medical dissertations, tried - primarily between 1880 and 1930 - to clarify what litigious paranoia was. A significant distinguishing feature of litigious paranoia for psychiatrists was a sense of justice which deviated from the snorm`. Accordingly, 
the highly influential psychiatrist Emil Kraepelin attributed litigious paranoia in the late 19th century to a hypersensitive sense of justice, ${ }^{35}$ the psychiatrist Heinrich Schüle postulated that a sufferer of litigious paranoia only had a limited sense of justice, ${ }^{36}$ and his colleague Gustav Specht spoke of an enhanced sense of justice, ${ }^{37}$ and the psychiatrist Julius Raeck surmised that litigious paranoia came from an overexcited sense of justice. ${ }^{38}$ In such psychiatric discourses, the drive behind querulency was taken to be a sense of justice that deviated from the norm. The abnormality of quarrelers was based on the fact that their sense of justice was seen to be exaggerated, excessive, unrestrained, and immoderate. The quarreler was observed to be an abnormal person, a personalized risk of the excessive sense of justice, and an individual in need of correction.

The concept quarreler (`Querulant`) was taken from legal-bureaucratic terminology and introduced as a term for an illness in the middle of the 19th century. With this, the forensic medical diagnosis pathologized not only the individual plaintiff but also the legal process-oriented nature of the claim; in other words, it pathologized the possibility of taking legal action. Therefore, the individual had become subject to the psychiatric diagnosis querulency, and that, against the backdrop that the constantly expanding psychiatry, was advising society to protect itself against possible litigious paranoia. The disease affected everyday people, above all, those who were socially dependent. For psychiatrists, litigious paranoia was primarily a disease of the subordinate class. Correspondingly, people in subordinate professions were registered in the files of the asylums when the psychiatrists were trying to diagnose the disease. The psychiatric power, however, also claimed to be able to diagnose litigious paranoia among those who were self-employed, in superordinate positions, wealthy, and powerful - albeit to a considerably lesser extent and with moderate success: district attorneys and mayors, landowners and representatives in the Reichstag, and district medical officers and project managers. For example, the president of the senate of the Higher Regional Court in Dresden, Daniel Paul Schreber - probably the most famous paranoiac in German media history - appears in the list of the querulent insane, at least as described
With these investigations of the excessive sense of justice, psychiatry entered not only the realm of jurisprudence but also areas and times of the general public. It was an institution that aided the legal system and additionally, as forensic medicine, began to provide considerable support for a comprehensive social project beginning in the early 19 th century. ${ }^{40}$ It penetrated the field of penal law with major, extreme, and monstrous cases, not only with the goal of exploring a new field of science but also to ensure and expand a form of power; since starting in the early 19th century, it was no longer the Prussian officials who determined who was a quarreler; the psychiatrists had already claimed the right to certify who, how, when, and where someone was querulous. They specified in most cases what querulency was, which social classes were infected by it, how it functioned, and what could make it worse or alleviate it. That had extensive consequences, as those diagnosed as having litigious paranoia - if their legal capacity was rescinded - were no longer treated as legally competent. As a result of this rescinding process (German Civil Law Code [BGB] § 6 No. 1 of the 18 August 1896/which took effect on the 1 January 1900), the individual was declared completely legally incompetent. These procedures for recognizing and treating disorders were a significant component in dealing with querulous persons in the late 19 th century. ${ }^{41}$

A large number of case histories about litigious paranoia around 1900 could be cited here. Psychiatrists meticulously collected everything that was classified as querulent insanity using the symptoms they established. From among these countless cases, one stands out in particular because problem areas in psychiatry are dealt with against a backdrop of media practices and a sense of justice.

In his discourse on the insane "Die Schrift bei Geisteskrankheiten. Ein Atlas mit 81 Handschriften" (The Handwriting of the Insane: An Atlas with the Handwriting of 81 Authors) [1903], which was put together out of material from the clinic in Gießen, the royal senior physician at the psychiatric clinic Rudolf Köster reproduced the writing of a 30 -year-old office clerk. Köster included the handwritten samples in his collection, as they were considered characteristic for the writing of the paranoid quarrelers..$^{42}$ The handwritten fragment in Köster's textbook is an administrative 
document. It is the application of the interned clerk for his release from the Gießen asylum. According to Köster, this fragmentary document was the neatest and most meticulous handwriting in the whole collection. Particularly emphasized by him were the written traces of the capital Gs in 'Gießen ‘ and 'Großh.ı,the curves that surround the author's address 'Hier (here) and the noun 'Freiheit، (freedom) as well as the straightness of the lines and the underlining in the seventh and eighth lines. Köster felt that these features were not evidence of pathological indicators in the handwriting, but rather were more a part of a strategy for intentionally covering up insanity to be released. In the diagnosis of the psychiatrist, the handwritten appeal for release raises the suspicion that the patient is diverting attention from his mental state, thus attempting to hide his own insanity. The hyperconformity of the resistance - exact line spacing or the perfect penmanship - is an indication of insanity for the psychiatrist. It was claimed that exactly because the office clerk had tried to hide his paranoid querulency by means of his correct writing that his insanity could be identified, justifying his further internment as a result.

More can be found in this diagnosis than one might originally expect. It is an example for how psychiatric observation tried to find pathological symptoms in normal situations and, using epistemic paths, diagnosed litigious paranoia. Paranoid litigious paranoia was a chronic mental illness for psychiatrists, during the course of which logic and memory remained for the longest time. For that reason, psychiatrists did not expect especially striking faults in writing as indicators of the disease. Paranoid litigious paranoia was not a form of insanity that physicians expected to recognize from shaky, awkward, hardly legible handwriting as was the case for progressive paralysis, epilepsy, or catatonic schizophrenia; it was rather a state that became noticeable from small distortions. This finding can be explained by the assumption that psychiatrists who investigated litigious paranoia were confronted with non-hallucinating deliria in which the psychic disposition of the patient remained without loss of intellect. The psychiatric knowledge about litigious paranoia consisted of the assumption that insanity was assumed, but that the patient appeared to behave eloquence, and had comprehensive knowledge of laws - observations which covered up the actual insanity. ${ }^{43}$ For that reason, Köster was able to assess the writing in this example as that of an insane person, even though it offers no evident signs of insanity. The reproduced text is used as proof, intended to substantiate the state of litigious paranoia. By means of the psychiatric description, the text became the text of a quarreler, as was the intention. ${ }^{44}$

This account of the text as an indicator and symptom, which at times grew into a fetishized glorification of the tiniest stroke of a pen among the graphological handwriting researchers, was connected with a modern ideology both of the subject and of the research of insanity. The deciphering and comprehension of human beings by means of handwriting analyses was based on a pseudoscientific creation of analogies and on simple recognition processes, with which a repressive system was established. To generate such an investigation of knowledge about querulency using a text, the text had to be overdetermined, the distance had to be dissolved between the temporality of the writing and the materiality of the text, and a relationship between the handwriting and the author had to be propagated which was based on a congruency of the two. ${ }^{45}$ As a pseudoscience, the graphological method was interested in written communication and concentrated on the psychic drives for abnormal handwriting. In the case of litigious paranoia, it prescribed examining the noise produced when writing and paying attention to the written product with which the basic noise of the graphically encoded message had started to be too noisy. ${ }^{46}$

Characteristic for the psychiatric observation investigated so far was that the analyses of the writing were followed by a neurological examination, namely in the sense that the written symbols were interpreted less as a result of a mechanical effect than as a reaction. This focus on the scheme annoying stimulus/ response was basic for the diagnosis of the disease pattern. After all, the act of writing - instigated by the stimulus and an abnormal sense of justice - was at the center of the diagnosis. When psychiatrists had their querulous patients write and reproduced the written documents in their textbooks, they attempted to create a system for determining relevant parameters. The 
reactions - according to the psychiatrists - revealed the dysfunctions. The behavioral analysis was based on the assumption that the writing was the reaction to stimuli. Handwriting was not a superb medium for demonstrating the existence of insanity; however, it was understood to be an opportune resource for diagnosing it. It served in individual cases to help determine accountability or lack of accountability in connection with the deed, when a physician had to be called upon to provide the court with an expertise.

Ever since the legal-bureaucratic figure of the querulous person has been investigated in forensic medicine, the research into the knowledge about querulency has focused on the written products and the writing process. Psychiatry has been assigned the task or has assigned the task to itself of determining whether individuals who have written offensive letters to the legal bureaucracy should be permitted to continue to write in freedom or should be sanctioned. The physicians needed graphological interpretations, because they were faced with a time problem. The psychiatric investigation of semantics, gestures, and writing tools served to help reconstruct the mental state during the process of writing a complaint. ${ }^{47}$ The writing of the querulous person was, on the one hand, considered to be a product, a written clue that indicated abnormality. On the other hand, the psychiatrists attempted to capture the temporality of the writing to make conclusions about the mental state of the author during the writing process. The handwriting on the paper became the storage medium for the insanity, as the physicians involved with graphology felt that the time of writing was displayed in it. In the psychiatric investigations on the written clue and the reconstruction of the individual querulous writing scene, the writing was examined to diagnose the people. This was relevant because the psychiatrists had to determine in an expertise whether insanity existed at the time when the petition or complaint was written. The handwriting confirmed the previous presence of the 'Querulantenwahnsinn (querulous insanity or paranoia).

\section{Michael Kohlhaas Syndrome}

Just as the quarrelers did not stop complaining, their reciprocal accusations as outlined above, the fields of confrontation and the sources of conflict have not dwindled to this day. Psychiatry and bureaucracy still are interested in querulency. The lines of observation of psychiatric and bureaucratic investigation naturally have changed; however, there are certain elements, such as the abnormal sense of justice and handwriting, the investigation of which has set the order for the discourse on querulency since the first administrative investigations. Today psychiatrists call plaintiffs who fight for their rights in such a manner >Rechtsparanoiker (legal paranoiacs). ${ }^{48}$

For the diagnosis process, writing remained a central indicator for psychiatry around 2000. "Numerous written expressions ${ }^{49}$ as well as "aggression in written form « ${ }^{50}$ are still, according to the best known forensic psychiatrist in Germany today, Henning Saß, the communication media and investigation media that are used to expose complaints as querulous writing and to expose claimants as querulous authors. Even after all the changes in the media conditions - from handwriting to typewriters to electronic word processing programs the main interest in psychiatry is concentrated around the handwritten or typographic image of the text. Even if the media possibilities for writing have changed, the relationship between writing and litigious paranoia - and thus using a plaintiff's writing to obtain social, administrative, and legal control over him - has never been abandoned. The psychiatrists Dietrich and Claasen, for example, still describe querulency using writing.

The legal quarrelers carried out their complaints for a considerably longer time and produced more writing (both more texts and more written volume). They frequently chose unusual formatting, used a large number of footnotes and glosses, applied different methods to emphasize content (marking text in different colors, underlining, capitalization), and stressed expressions considered important with quotation marks or repeated punctuation (`???^ or ^!!!`). ${ }^{51}$

This psychiatric attention and the exploitation of writing are a reason why a literary figure who was established by his own writing has become one of the most stable points of reference in the history of querulency in modern psychiatry: The uncontested star among the quarrelers and troublemakers is Michael Kohlhaas from Heinrich von Kleist's novella of the 
same name. Psychiatrists who deal with the nosology of litigious paranoia have been remarkably intensively attracted to the novella. By reading psychiatric and legal literature, one can recognize that this story has had and still has a special significance in setting up psychiatric and legal knowledge. From the end of the 19th century up until today, Michael Kohlhaas has been an integral part of the psychiatric-forensic discussion about querulency. The subordinate horse dealer Kohlhaas, whom Kleist initially described as a supplicant, is described in modern psychiatric literature as a >legal paranoiac . ${ }^{52}$ For the psychiatrist Saß, the novella functions as an example, or more precisely, as a »literary example for exorbitantly excessive querulency «. ${ }^{33}$ By means of the assessment of the fictitious actions and considerations of the horse trader, a "fanatic querulous development in its [...] classic form ${ }^{54}$ is attributed to the literary figure. What becomes evident upon reading this psychiatric literature is the career of a literary figure and the description of a disease that textbooks have called the "Michael Kohlhaas syndrome« ('paranoid personality disorder [ [ICD-10: F 60.0]) in recent years. ${ }^{55}$

The story serves as an example in psychiatric as well as legal studies, which show the extent to which laws and the collision with bureaucratic forms can lead to insanity and that latent dangers can erupt violently. Michael Kohlhaas is not just an imaginary horse trader who together with his fellow troublemakers burns down towns in Saxony and Brandenburg but also a literary figure who above all does one thing - he writes. Numerous written documents are submitted, received, and stored in increasingly larger files - including appeals, 'Suppliken`, petitions, and protest letters. In the activities that are caught up in the process of submitting and receiving official documents, Kleist described an institutional power reflex of the Prussian bureaucracy around 1800, which wished to stop and suppress the obstinate demands of the horse trader, as the administrative machinery recognized that it would be overwhelmed by Kohlhaas's subsequent media responses, thus limiting its scope of possible actions. Here, Michael Kohlhaas is understood by the judiciary officials to be a figure caught up in excessive appeals. Since the files keep getting larger, he is discredited as a "quarrelsome fellow «. ${ }^{56}$ The quarrelsome fellow
Kohlhaas that was made against him by psychiatrists around 1900 and 2000 - roaring noise in the communication channels of various legal institutions by means of written documents. Querulency can cause this, and that is the starting point for my considerations, because it is a media-technical product of writing.

This is also a reason why the novella "Michael Kohlhaas« has been at the center of legal-bureaucratic deliberations on legal access, control over writing, and the sense of justice. This applies for both legal philosophical and legal theoretical discussions in the past as well as for contemporary controversies that concern the Supreme Court of the Federal Republic of Germany. The novella is at least for Horst Sendler, the president of the German Federal Administrative Court between 1980 and 1991, the starting point for his thoughts on the so-called 'Kohlhaas-Typ (Kohlhaas figure). A 'Kohlhaas figure is a petitioner in whom an obsession (fixe Idee) can be observed. ${ }^{57}$ Sendler felt that it amounts to a petitioner falling into the erroneous assumption that he was continually being deprived of his rights and that these petitioners are people whose sense of justice displays psychopathic traits. The 'Kohlhaas figure is described as something parasitic and is observed to be a petitioner whose emotions present a problem for the administration and who applies admissible legal means excessively. The reason for this behavior is sought solely in the emotional economy of the person, and severe forms of personality disorders are called upon to make a literary figure into a representative of litigious paranoia. These petitioners are considered problematic, not only for the work of the German Federal Administrative Court in Leipzig but also for the administration of justice at the German Supreme Constitutional Court in Karlsruhe.

The present president of the German Supreme Constitutional Court, Andreas Voßkuhle, has also posed the question as to which challenges this type of petitioner represents for the democratically constituted community. ${ }^{58}$ This takes into account that the novella presents numerous answers that have been discussed in literary and law studies: It is the literary imagination of the maintenance of legal security, of a malicious legal deception, and of a damnation and absolution of a petitioner at the same time. The serious legal issues of the case are assumed to be found in the fact that 
Michael Kohlhaas is judged to be a 'Querulant >criminal and is simultaneously acquitted. Apparently, the properties of the novella have an impact that bring about connections and exchange processes, and here as well the novella apparently advances epistemologically relevant actions concerning the sense of justice of petitioners. It is cited to discuss the 'Kohlhaas constellation ‘ in contemporary jurisdictions and therefore also the sense of justice. Kohlhaas is understood to be a social figure in the present, about whose dangerous nature warnings as it were are issued. The risk that emanates from Kohlhaas arises from the fact that the novella places a higher priority on the sense of justice than on positive rights. Following this line of thinking, the error in the 'Kohlhaas figure consists of not understanding the difference between the promise of legal rights and the promise of fair justice. What is spelled out here is what one so often hears from scholars of law and what this paper is arguing against, namely that the experiences regarding law and justice and illegal and unjust, as well as every application of the law, are the works of man. ${ }^{59}$ This approach ignoring the media is applied to that novella, in which literary reflections on the relationships between things, media, and cultural tools are presented in an extremely dense manner, and the extent to which media determine the administration of justice and the emotions of those involved is related. The sdescendants, of Michael Kohlhaas are less frequently citizens who are charged with rage and who violently fight for their rights, but rather petitioners who clog up the communication channels of jurisprudence. They impede the exercising of judgments because they overload the working capacity of the courts with topicless complaints. The German Supreme Constitutional Court hears more than 6,000 appeals a year - most of which, according to the court, were written in vain, because right from the start they had no chance of success. ${ }^{60}$

The provisions and arrangements for storing, transferring, and deleting appeals, according to the persistent discourse among those responsible at the Constitutional Court, are used so excessively by some petitioners that the administration of the appeals is overloaded. Here, the processing of large volumes of data at the Constitutional Court is pointed out. One must consider that the petitioners appealing to the
German Supreme Constitutional Court have already gone through numerous levels of appeal at lower courts, which in many cases have rejected their demands, and that the Constitutional Court is their last resort to receive justice. Someone who sends an appeal to Karlsruhe (or delivers it personally at the entrance) has usually already gone through an initial appeal (Berufung), a revision (Revision), an immediate complaint bound to a time period (sofortige Beschwerde), a legal complaint (Rechtsbeschwerde), and a complaint against the denial to appeal (Nichtzulassungsbeschwerde) - and has still not given up hope of receiving his or her rights. The German Supreme Constitutional Court in Karlsruhe is the last resort for appeals within the German court system - petitioners have to pass through all the other appellate possibilities before filing an appeal there. Processing the petitions submitted by the plaintiffs is not always possible - according to those responsible - because the court is overloaded with excessive claims, some produced by parasitic `Kohlhaas figures`. Depending on the severity of the criteria used, the proportion of querulous claims filed with Germany's Supreme Court ranges from one-tenth to one-third of the filings. ${ }^{61}$

The complaint that querulous entries reduce the working capacity of the courts is as old as the querulous figures themselves and the development of the sense of justice in the 18th century. In addition, the subject gains importance with the question of appeals to the Constitutional Court. In the discussions on the sense and future of appeals to the Constitutional Court the argument was introduced at the outset that as an exaggeration in the legal system they encouraged the querulous petitioners and unduly extended legal disputes. ${ }^{62}$ But somehow - and this may be an indication of how inherent querulent behavior and the emotional components are to the system - those with responsibilities at the court have been surprised and irritated since the court was founded by the fact that the Constitutional Court has been confronted with querulous claims. In 1952, shortly after the Constitutional Court was founded, its vice president, Rudolf Katz, reported that four-fifths of the more than 1,500 claims that had been filed so far were submitted by "notorische Querulanten« (notorious querulents) and »Geisteskranker" (the mentally ill). ${ }^{63}$ 
The emotional moment in appealing to the Constitutional Court is based on the fact that the petitioner has to make clear that his rights and obligations were infringed upon, as they have been laid out in the Constitution, or that his rights and obligations are in immediate danger. Any man or woman can file an appeal with the German Constitutional Court (§ 90 Abs. 1, BVerfGG) if they feel that the public authority has violated their fundamental rights (Art. 1 - 19 GG) or rights that are equivalent to their fundamental rights (Art. 20 Abs. 4, Art. 33, 38, 101, 103, 104 GG) and the petitioner is sgrundrechtsfähig، (legally accountable) and 'grundrechtsmündig، (legally of age) ${ }^{64}$ In addition, no costs accrue for cases at the German Constitutional Court ( $\$ 34$ Abs. 1 BVerfGG), as the application of fundamental constitutional rights is not linked to any financial considerations. The petitions vary considerably and have ranged since the foundation of the court from basic questions of government law, to complaints about judges, decisions on fines or prison conditions, entitlements to war pensions, and increasingly in recent times to rental disputes.

The medial peculiarity of appeals to the Constitutional Court results from the fact that they have to be submitted in writing ( $§ 23$ Abs. 1, § 92 BVerfGG) and that there is a set address for such appeals. They have to be sent via the postal service (address: Bundesverfassungsgericht, Postfach 1771, 76006 Karlsruhe) or by fax (fax no.: +49 (721) 9101-382). Writing an appeal to the Constitutional Court is not particularly difficult: It can be handwritten, written with a typewriter, or printed using a computer, as there are no official forms or questionnaires. However, the petitioners must name the jurisdictional measures involved that resulted in an infringement of the petitioners' constitutional rights, the petitioners themselves must have been affected, and they must have already exhausted all other legal means. An appeal to the Constitutional Court cannot be submitted as an email for fear that the use of digital media might multiply the noise in the information channels. As a result of a review of the paper records of the German Constitutional Court, the so-called 'Q , index was created. ${ }^{65}$ The paper entries are the representation and perception medium for determining a spsychic escalation ‘ and for identifying the messages as "Eingänge mit deutlich 'querulous ‘ form) ${ }^{66}$ The medial conditions for possibly discovering querulency have - since the discovery of the querulous figure in the Prussian bureaucracy of the late 18 th century - been written sentences and the sense of justice.

Remarkably, within the history of querulency, the parameters in the systems used for recognizing this behavior have remained relatively stable over the last 200 years. That applies, on the one hand, to identifying querulency via the medial operations sending and receiving, the cultural technique of writing, and the determination of a psychic abnormality or the diagnosis of an abnormal sense of justice. On the other hand, there is still the name-giving abuse at the center of the process for determining querulency. At the moment, this is most intensely recognizable in the legal political discussion about sabuse fees a and the introduction of a 'willfulness feer at the Constitutional Court. The sabuse fee` (`Missbrauchsgebühr` 33 Abs. 2 BVerfGG) makes it possible, despite the stipulation that no fees should accrue, to charge the petitioner a fee for abuse of up to 2,600 euros. In this way, petitioners to the Constitutional Court who correspond to the Kohlhaas figure are to be discouraged from submitting querulous claims to the court. The problem, however, is that the regulations do not include a clear definition of abuse ${ }^{67}$

If one summarizes the problem areas described above, it can be noted that querulency is defined as a breaking point at the German Supreme Constitutional Court even today. The petitioners who are considered to be a disturbance as a result of their sense of justice are effectively and extensively excluded from the system of jurisprudence in which they are included. This moment of exclusion and inclusion makes clear who, when, how, and where decisions thought to be reasonable go beyond acceptable measures. By means of such a configuration of querulency - as a moral, economic, and judicial injury - it has been possible to maintain this legal-bureaucratic figure up to the present day. Someone who is identified as having the >Michael Kohlhaas syndromer is not entitled to file an appeal with the German Constitutional Court.

The novella >Michael Kohlhaas, is cited in legal discourse to consider the significance of the fight for rights and the fight for justice in today's society. A novella is used by judicial decision-makers as a test case 
for contractual forms for the justification of jurisdiction. Michael Kohlhaas does not rebel against the state, but rather revolts against the absence of legal security in the state involved. What drives the modern Kohlhaas is his sense of justice, according to the president of the Constitutional Court, who claimed that where the sense of justice is not in agreement with positive rights people such as Kohlhaas take action. In his opinion, the modern legal order is extremely susceptible to an injured sense of justice and provides a multitude of possibilities for appeal, and the perception of injustice can be reported by anyone to create a court case out of it. Voßkuhle said the problem with Kohlhaas is that there is no difference for such petitioners between individual perceptions of justice and general laws ${ }^{68}$ and that the modern Kohlhaas is only concerned with satisfying his own sense of justice.

In addition, courts such as the German Constitutional Court are confronted with numerous petitioners who claim to be better informed about the law than the judges. This has been recorded in countless letters to the Constitutional Court, which deal with the petitioner's sense of justice. The reason this can be observed can be found in the fact that since the early 18th century the laws have supported the petitioning process and evoked appeals. 'Michael Kohlhaas has great significance for the present legal situation and dealing with the sense of justice because the novella shows the extent to which querulency represents a dark side of bureaucratic situations. The administration of justice in a democracy depends on institutions and processes as well as media, which provide for the transfer, storage, and deletion of information to mobilize justice. When the conditions for achieving justice, the overloaded courts, and the emotions of querulous persons are being discussed, those media of bureaucracy come into focus without which the appeals would not be possible.

Following this cursory history of querulency, from its beginnings in the Prussian bureaucracy around 1800 up to current psychiatric and legal-bureaucratic discussions, three relevant aspects of a media-scientific examination of querulency can be identified. First, we can say that querulency is a media phenomenon in communication which historically has been based on each of the different forms of media and at the and infrastructures have been involved that have been instigated since the 18th century so that our knowledge about human beings and their sense of justice can be recorded and passed on. At the same time, text diagnostic processes are intended that have been used in bureaucracy and psychiatry to diagnose a case of litigious paranoia. Second, we can say that an observation of the troubling practices and troubling media mentioned here make an investigation of the exclusion procedures and the rituals developed for ascertaining truth possible. This appears to be crucial because it is these procedures and rituals in particular that define speech as querulous speech, a text as a querulous text, and a sense as a querulous sense. A media-historical investigation of querulency as briefly outlined here must examine intentionally set up legal and social structures that can be deliberately broken by overloading them. Still today, one such breaking point is the psychiatric diagnosis litigious paranoia, which has been and still is dependent on individual views on how, when, and where a sense of justice is attested to be normal or abnormal. Third and finally, we can say that querulency involves minor professional polemic activities. Querulency, namely, is a specific critical stance, and furthermore, it has been observed to be an unusual hypercritical activity since the 18th century. Anyone who criticizes takes a specific stance - using specific forms of speech, taking specific forms of action, understanding situations in specific ways, and feels in specific ways. Therefore, the individuals put themselves in a specific perspective: They establish a relationship to certain knowledge, to attitudes in society, to institutions and media, to those people closest to them and those most distant. The accounts about people who have been observed as being quarrelers and troublemakers in the past and still are today indicate when a society itself maintains that the sense of justice has become excessive. Translated by Bruce W. Irwin 
1 'Quarrelerss, squerulistsı, or squerulous people at courts, from Latin: queri, to complain.

2 Henning Saß: „Der Exzess einer Tugend. Querulanz zwischen Persönlichkeit, Strukturverformung und Wahn«, in: Forensische Psychiatrie, Psychologie, Kriminologie 4 (2010), pp. 223-232, at p. 223.

3 See Eric A. Posner: »Law and the Emotions«, in: University of Chicago Law Occasional Paper 42 (2001), pp. 1-36; Brian Bornstein / Richard Wiener (ed.): Emotion and the Law. Psychological Perspectives, New York 2009; Terry A. Maroney: „Emotional Regulation and Judicial Behavior«, in: California Law Review 99 (2011), pp. 1485-1556.

4 Christoph Meier: Zur Diskussion über das Rechtsgefühl. Themenvielfalt - Ergebnistrends - neue Forschungsperspektiven, Berlin 1986; Hilge Landweer / Dirk Koppelberg (ed.): Recht und Emotion. Verkannte Zusammenhänge, Freiburg im Breisgau 2016 and Sigrid G. Köhler / Sabine Müller-Mall / Sandra Schnädelbach: Recht fühlen, München 2017.

5 On the relevance of the historicity of emotions in historical studies, see Ute Frevert: Emotions in History - Lost and Found, Budapest 2011; Ute Frevert / Thomas Dixon: Emotions in History. Continuity and Change in the Vocabulary of Feeling 1700-2000, Oxford 2014.

6 Michel Foucault: »The Subject and Power«, in: Michel Foucault: Power. Essential Works, Vol. 3, ed. by James D. Faubion, translated by Robert Hurley, New York 2000, pp. 326-348.

7 Birgitt Rehse: Die Supplikations- und Gnadenpraxis in BrandenburgPreußen. Eine Untersuchung am Beispiel der Kurmark unter Friedrich Wilhelm II. (1786-1797), Berlin 2008.

8 On the petitioning or ssupplication system ('Supplikationspraxis) in Prussia in the 18th century, see Wolfgang Neugebauer: »Zur neueren Deutung der preußischen Verwaltung im 17. und 18. Jahrhundert in vergleichender Sicht«, in: Otto Büsch / Wolfgang Neugebauer (ed.): Moderne Preußische Geschichte 1648-1947. Eine Anthologie, Vol. 2, Berlin 1981, pp. 541-597.

9 See Karl Dickel: Beiträge zum preußischen Rechte für Studierende und Referendare, Marburg an der Lahn 1891; Eberhard Schmidt: "Kammergericht und Rechtsstaat. Eine Erinnerungsschrift", in: Moderne Preußische Geschichte 1648-1947, Vol. 2, pp. 622-648; David Martin Luebke: »Frederick the Great and the Celebrated Case of the Millers Arnold (1770-1779). A Reappraisal«, in: Central European History 32 (1999), pp. 379-408.

10 See the Supplik from Rosine Arnold to Friedrich II., printed in Malte Diesselhorst: Die Prozesse des Müllers Arnold und das Eingreifen Friedrichs des Großen, Göttingen 1984, pp. 75-76.

11 Michel Foucault: »Lives of Infamous Men«, in: Foucault: Power, pp. 157-175 and Arlette Farge / Michel Foucault: Disorderly Families. Infamous Letters from the Bastille Archives, Minneapolis, Minnesota 2016, pp. 251-266.

12 See Sandro-Angelo Fusco et al.: „Verwaltung, Amt, Beamter«, in: Otto Brunner / Werner Conze / Reinhart Koselleck (ed.): Geschichtliche Grundbegriffe. Historisches Lexikon der politisch-sozialen Sprache in Deutschland, Vol. 7, Stuttgart 1992, pp. 1-96 and Michael Stolleis: Geschichte des öffentlichen Rechts in Deutschland. Vol. 1: Reichspublizistik und Policeywissenschaft 1600-1800, München 1988, pp. 366-369.

13 Friedrich Kittler: Discourse Networks, 1800/1900, translated by Michael Metteer with Chris Cullens, Stanford 1990, pp. 53-69.

14 Michel Foucault: The Order of Things. An Archaeology of the Human Sciences, London 2002, pp. 371-373.

15 Cornelia Vismann: Files. Law and Media Technology, translated by Geoffrey Winthrop-Young, Stanford 2008, pp. 109-117. cultural techniques for law can be followed back to the work of the Romance language literary scholar Ernst Robert Curtius. At the beginning of the 1950s, he investigated the report keeping of J. W. Goethe, that is, his filing, copying, and cancelation techniques. According to Curtius, for the civil servant Goethe, files as a legalbureaucratic medium became crucial for his self-administration as an author and for the literature that resulted from his work. Classic German literature therefore becomes literature produced from files and Goethe a subject of the files. Ernst Robert Curtius: "Goethe as Administrator «, in: Ernst Robert Curtius: Essays on European Literature. Translated by Michael Kowal, Princeton 1973, pp. 58-72.

17 Historically, efforts mostly focused on criticism of psychiatry and the so-called IIrrenbroschüren«. Cf. Cornelia Brink: Die Grenzen der Anstalt. Psychiatrie und Gesellschaft in Deutschland 1860-1980, Göttingen 2010, pp. 165-192; Rebecca Schwoch: »Mein jahrelanger Kampf gegen den Psychiater Größenwahn،. IIrrenbroschüren als Form einer Psychiatriekritik um 1900«, in: Christine Wolters et al. (ed.): Abweichung und Normalität. Psychiatrie in Deutschland vom Kaiserreich bis zur Deutschen Einheit, Bielefeld 2013, pp. 71-95 and Rebecca Schwoch / Heinz-Peter Schmiedebach: "Querulantenwahnsinn<, Psychiatriekritik und Öffentlichkeit um 1900«, in: Medizinhistorisches Journal 42 (2007), pp. 30-60.

18 Sense of justice is a decisive factor in legal questions, which, however, many involved in the administration of justice frequently conceal. The fine distinction between the sense of justice and emotional jurisprudence is said to be too narrow. This is complicated by the fact that legal scholars point out that the sense of justice is relevant in the rationale used in deciding a case - for example, when applying subsumption. The legal case will initially be grasped intuitively and later justified with legal arguments: Ideals, characteristic properties attributed to the case, and social and political circumstances determine the decisions just as much as laws and precedents. The decision must ensure that the standards applied are suitable for the circumstances, and this is recognized as one of the criteria for a sense of justice. Cf. Gerhard Sprenger: »Rechtsgefühl ohne Recht. Anthropologische Anmerkungen«, in: Gerhard Sprenger: Von der Wahrheit zum Wert. Gedanken zu Recht und Gerechtigkeit, Stuttgart 2010, pp. 305-326; Meier: Zur Diskussion über das Rechtsgefühl; and Sabine Müller-Mall: "Zwischen Fall und Urteil. Zur Verortung des Rechtsgefühls», in: Thomas Hilgers et al. (ed.): Affekt und Urteil, München 2015, pp. 117-131.

19 Karl Peters: »Reaktion und Wechselspiel. Zur Problematik des Begriffs 'Querulant` aus strafprozessualer Sicht«, in: Manfred Just (ed.): Recht und Rechtsbesinnung. Gedächtnisschrift für Günther Küchenhof (1907-1983), Berlin 1987, pp. 457-469; and Gerhard Möllhoff: "'Querulanten<. Anmerkungen zu einem unerschöpflichen Thema in der forensischen Psychiatrie«, in: Hans Binder (ed.): Macht und Ohnmacht des Aberglaubens, Pähl 1992, pp. 182-199.

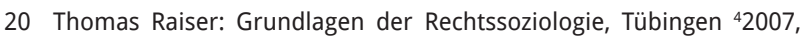
pp. 319-322.

21 Gustav Radbruch: „Über das Rechtsgefühl«, in: Gustav Radbruch: Gesamtausgabe, Vol. 1, ed. by Arthur Kaufmann, Heidelberg 1987, pp. 423-429.

22 Raimund Jakob / Manfred Rehbinder (ed.): Beiträge zur Rechtspsychologie, Berlin 1987.

23 Of little avail was the early attempt to produce an initial systematic history of the sense of justice by Sigmund Kornfeld: „Das Rechtsgefühl«, in: Zeitschrift für Rechtsphilosophie 1 (1914), pp. 135-187; and Sigmund Kornfeld: „Das Rechtsgefühl«, in: Zeitschrift für Rechtsphilosophie 2 (1919), pp. 28-100. 
24 Johannes F. Lehmann: »Zorn, Rache, Recht. Zum Bedingungsverhältnis zwischen Affekt- und Straftheorie (von der Aufklärung bis zum Ende des 19. Jahrhunderts)«, in: Maximilian Bergengruen / Roland Borgards (ed.): Bann der Gewalt. Studien zur Literatur- und Wissensgeschichte, Göttingen 2009, pp. 177-226.

25 Robert Weimar: "Rechtsgefühl und Ordnungsbedürfnis«, in: ErnstJoachim Lampe (ed.): Das sogenannte Rechtsgefühl, Opladen 1985, pp. 158-172; Monika Emilia Miranowicz: Gehirn und Recht. Wie neurowissenschaftliche Erkenntnisse das Dilemma zwischen Naturrecht und Positivismus überwinden können, Berlin 2009, p. 55; and Heinz Müller-Dietz: »Rechtsgefühl, Schuldgefühl, Vergeltungsund Sühnebedürfnis«, in: Lampe: Das sogenannte Rechtsgefühl, pp. 37-54, at pp. 38-40.

26 Meier, Zur Diskussion über das Rechtsgefühl, pp. 14-24.

27 On this aspect from a cultural studies perspective, see Hartmut Böhme: „Gefühl«, in: Christoph Wulf (ed.): Vom Menschen. Handbuch Historische Anthropologie, Basel 1997, pp. 525-548.

28 Johann Ludwig Casper: Practisches Handbuch der Gerichtlichen Medizin nach eigenen Erfahrungen bearbeitet, Vol. 1, Berlin ${ }^{3} 1860$, p. 501.

29 Eric J. Engstrom: »Assembling Professional Selves. On Psychiatric Instruction in Imperial Germany«, in: Eric J. Engstrom / Volker Roelcke (ed.): Psychiatrie im 19. Jahrhundert. Forschungen zur Geschichte von psychiatrischen Institutionen, Debatten und Praktiken im deutschen Sprachraum, Basel 2003, pp. 116-152; and Dirk Blasius: >Einfache Seelenstörung؛. Geschichte der deutschen Psychiatrie 1800-1945, Frankfurt am Main 1994, pp. 41-59.

30 Casper: Practisches Handbuch, p. 574; Carl Wernicke: „Über fixe Ideen«, in: Deutsche Medizinische Wochenschrift 18 (1892), pp. 581582.

31 Droste: „Ein widerwärtiger lästiger Querulant«, in: Vierteljahrsschrift für Psychiatrie in ihren Beziehungen zur Morphologie und Pathologie des Central-Nervensystems, der physiologischen Psychologie, Statistik und gerichtlichen Medicin 2 (1868), pp. 73-77.

32 Friedrich Scholz: "Zwei psychiatrische Gutachten. Von Dr. Friedr. Scholz, K. Kreis-Physikus u. dirigir. Arzt des Hospitals der Barmh. Brüder zu Steinau a./O. [...] 2. Ein wahnsinniger Querulant«, in: Vierteljahrsschrift für gerichtliche und öffentliche Medicin. Unter Mitwirkung der königlichen wissenschaftlichen Deputation für das Medicinalwesen im Ministerium der geistlichen, Unterrichts- und Medicinal-Angelegenheiten 8 (1868), pp. 343-355.

33 Richard von Krafft-Ebing: „Über den sogenannten Querulantenwahnsinn«, in: Allgemeine Zeitschrift für Psychiatrie und psychisch-gerichtliche Medicin 35 (1879), pp. 395-419.

34 Jacques Lacan: „On a Question Preliminary to any Possible Treatment of Psychosis«, in: Jacques Lacan: Écrits. A Selection, translated by Alan Sheridan, London 2001, pp. 137-172, at p. 169.

35 Emil Kraepelin: Psychiatrie. Ein Lehrbuch für Studierende und Ärzte, Vol. 2, Leipzig 61899, p. 447.

36 Cited in Julius Raecke: Der Querulantenwahn: Ein Beitrag zur sozialen Psychiatrie, München 1926, p. 11.

37 Cited in Raecke: Der Querulantenwahn, p. 13.

38 Cited in Raecke: Der Querulantenwahn, p. 75.

39 Sigmund Freud - Karl Abraham: Briefe 1907-1926. ed. by Hilda C. Abraham and Ernst L. Freud, Frankfurt am Main ${ }^{21980, ~ p . ~} 272$.

40 Michel Foucault: »About the Concept of the sDangerous Individual in Nineteenth-Century Legal Psychiatry«, in: Foucault: Power, pp. 176-200.

41 For more on the practice of internment and incapacitation and the effects of turning this into a public scandal - shown here using the Landesheilanstalt Marburg as an example - see Karen Nolte:
Gelebte Hysterie. Erfahrung, Eigensinn und psychiatrische Diskurse im Anstandsalltag um 1900, Frankfurt am Main 2003, pp. 92-102, 104-112.

42 Rudolf Köster: Die Schrift bei Geisteskrankheiten. Ein Atlas mit 81 Handschriften, Leipzig 1903, p. 161.

43 For more on querulous insanity as a form of insanity devoid of affective or hallucinatory symptoms, see Cornelius Borck / Sonja Mählmann: »Der Querulantenwahn - oder wie die Psychiatrie zu ihrem Recht kam«, in: Heinz-Peter Schmiedebach (ed.): Entgrenzungen des Wahnsinns. Psychopathie und Psychopathologisierung um 1900, München 2016, pp. 241-258, at p. 247.

44 For another example, see Rupert Gaderer: "Querulantenwahnsinn<. Papierflut, Graphologie und Rechtsgefühl«, in: Cornelius Borck / Armin Schäfer (ed.): Das psychiatrische Aufschreibesystem, München 2015, pp. 181-199.

45 Stephan Kammer: »Reflexionen der Hand. Zur Poetologie der Differenz zwischen Schreiben und Schrift», in: Davide Giuriato / Stephan Kammer (ed.): Bilder der Handschrift. Die graphische Dimension der Literatur, Frankfurt am Main 2006, pp. 131-161, at p. 138.

46 Michel Serres: „Platonic Dialogue«, in: Michel Serres: Hermes. Literature, Science, Philosophy, ed. by Josué V. Harari / David F. Bell, Baltimore 1982, pp. 65-70.

47 Rupert Gaderer: »Querulatorisches Schreiben. Paranoia, Aktenberge und mimetischer Parasitismus um 1900«, in: ZMK. Zeitschrift für Medien- und Kulturforschung 4 (2013), pp. 37-51.

48 Horst Dilling / Christian Reimer: Psychiatrie und Psychotherapie, Berlin ${ }^{31997, ~ p . ~ 65 ; ~ V o l k e r ~ A r o l t ~ / ~ H o r s t ~ D i l l i n g ~ / ~ C h r i s t i a n ~ R e i m e r: ~}$ Basiswissen Psychiatrie und Psychotherapie, Berlin ${ }^{72011}$, p. 43.

49 Henning Saß: "Persönlichkeit, Strukturverformung und Wahn am Beispiel der Querulanz«, in: Frank Schneider (ed.): Positionen der Psychiatrie, Berlin 2012, pp. 280-288, at p. 285.

50 Saß: »Persönlichkeit, Strukturverformung und Wahn am Beispiel der Querulanz«, p. 287.

51 Detlef E. Dietrich / Bastian Claassen: »Querulantenwahn«, in: Petra Garlipp / Horst Haltenhof (ed.): Seltene Wahnstörungen, Heidelberg 2010, pp. 132-140, at p. 134. Dietrich and Claasen refer to the studies of Grant Lester et al.: "Unusually persistent complainants", in: British Journal of Psychiatry 184 (2004), pp. 352-356 and Paul E. Mullen / Grant Lester: „Vexatious Litigants and Unusually Persistent Complainants and Petitioners: From Querulous Paranoia to Querulous Behaviour«, in: Behavioral Sciences \& the Law 24 (2006), pp. 333-349.

52 Dilling / Reimer: Psychiatrie und Psychotherapie, p. 65; Arolt / Dilling / Reimer: Basiswissen Psychiatrie und Psychotherapie, p. 43.

53 Saß: "Der Exzess einer Tugend», p. 224.

54 Paul Hoff / Henning Saß: "Psychopathologische Grundlagen der Forensischen Psychiatrie«, in: Hans-Ludwig Kröber et al. (ed.): Handbuch der forensischen Psychiatrie, Vol. 2: Psychopathologische Grundlagen und Praxis der Forensischen Psychiatrie im Strafrecht, Berlin 2011, pp. 1-156, at p. 84.

55 Theo R. Payk / Martin Brüne: Checkliste Psychiatrie und Psychotherapie, Stuttgart ${ }^{6} 2007$, p. 245; Matthias Lammel: »Querulanz und Querulantenwahn. Anmerkungen aus forensisch-psychiatrischer Sicht zu: J. Raecke: ১Der Querulantenwahn. Ein Beitrag zur sozialen Psychiatrie« (1926)«", in: Matthias Lammel / Stephan Sutarski (ed.): Wahn und Schizophrenie. Psychopathologie und forensische Relevanz, Berlin 2011, pp. 233-248, at p. 236.

56 Heinrich von Kleist: Michael Kohlhaas. Translated by Martin Greenberg, New York 1960, p. 18. 
57 Horst Sendler: Michael Kohlhaas, gestern und heute, Berlin 1985, p. 25.

58 Andreas Voßkuhle / Johannes Gerberding: "Michael Kohlhaas und der Kampf ums Recht«, in: Juristen Zeitung 67 (2012), pp. 917-925, at p. 917.

59 Voßkuhle / Gerberding: »Michael Kohlhaas und der Kampf ums Recht«, p. 923.

60 See the statistics published annually online by the German Supreme Constitutional Court under: http://www.bundesverfassungsgericht. de/DE/Verfahren/Jahresstatistiken/Archiv/Archiv.html (downloaded on 3 March 2017).

61 Erhard Blankenburg: „Die Verfassungsbeschwerde - Nebenbühne der Politik und Klagemauer von Bürgern«, in: Kritische Justiz. Vierteljahresschrift für Recht und Politik 31 (1998), pp. 203-218, at pp. 209-210; Erhard Blankenburg: „Unsinn und Sinn des Annahmeverfahrens bei Verfassungsbeschwerden«, in: Zeitschrift für Rechtssoziologie 19 (1998), pp. 37-60, at p. 38.

62 Rüdiger Zuck: Das Recht der Verfassungsbeschwerde, München ${ }^{4} 2013$, Rn 154.

63 Cited from Heinz Laufer: Verfassungsgerichtsbarkeit und politischer Prozess. Studien zum Bundesverfassungsgericht der Bundesrepublik Deutschland, Tübingen 1968, p. 172/Fn 9. On the German Supreme Constitutional Court's overload see also Christoph Gusy: „Die Verfassungsbeschwerde«, in: Martin H.W. Möllers / Robert Chr. van Ooyen (ed.): Das Bundesverfassungsgericht im politischen System, Wiesbaden 2006, pp. 201-213, at p. 208; Ernst-Wolfgang Böckenförde: "Die Überlastung des Bundesverfassungsgerichts«, in: Zeitschrift für Rechtspolitik 29 (1996), pp. 281-284.

64 Klaus Schlaich / Stefan Korioth: Das Bundesverfassungsgericht,

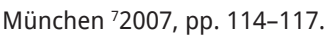

65 Blankenburg: "Unsinn und Sinn des Annahmeverfahrens bei Verfassungsbeschwerden«, p. 46.

66 Blankenburg: „Unsinn und Sinn des Annahmeverfahrens bei Verfassungsbeschwerden«, p. 47; Ludger Wellkamp: »Querulanz vor dem Bundesverfassungsgericht«, in: Jürgen Brand / Dieter Strempel (ed.): Soziologie des Rechts. Festschrift für Erhard Blankenburg zum 60. Geburtstag, Baden-Baden 1998, pp. 569-575, at p. 573.

67 In the administration of justice in the chambers s groups of cases ' have arisen in which abuse has attracted attention: completely hopeless claims, that is, "obviously inadmissible and unfounded constitutional appeals" (primarily from lawyers), "repeated submission of futile constitutional appeals for cases with parallel presentations", "continuation of a constitutional appeal after inadmissibility has been entered in the General Register", "petty cases", "false statements and deception about case facts«, »instrumentalization of constitutional appeals«, "appeals and complaints with a libelous or defamatory character«. See Christian Burkiczak / Franz-Wilhelm Dollinger / Frank Schorkopf (ed.): Bundesverfassungsgerichtsgesetz (Heidelberger Kommentar), Heidelberg 2015, pp. 672-677, at p. 673. On the rabuse feer see Monika Winkler: Die Missbrauchsgebühr im Prozessrecht. Ein Beitrag zu Missbrauchsgebühren nach § 34 Abs. 2 BVerfGG und nach § 192 Abs. 1 Nr. 2 SGG im Kontext prozessualer Kostensanktionen, Tübingen 2011.

68 Voßkuhle / Gerberding: "Michael Kohlhaas und der Kampf ums Recht«, p. 924. 


\section{Abstract}

At the end of the 18th century, reports were made of unusual and curious legal cases in which the plaintiffs were moved by a self-destructive obsession. These excessive desires expressed themselves in the fact that these people were involved in countless lawsuits and vied in vain for their rights in court. These plaintiffs were people who studied the law obsessively, meticulously filed suit after suit, and continuously troubled civil servants with unjustified legal demands. The Prussian bureaucracy gave these plaintiffs a name: ‘Querulanten (from Latin: queri, to complain). This paper deals with the history of these troublemakers, and more particularly, with the goal of understanding the source, development, and the continuing existence of querulency as a connection between media, knowledge, and emotions.

\section{About the Author}

PD Dr. Rupert Gaderer holds currenty a position as a Akademischer Oberrat at Ruhr-University Bochum, Department of German. He was a fellow at the Austrian Academy of Sciences (ÖAW, Vienna), the International Research Center for Cultural Studies (IFK, Vienna), the Humboldt-University of Berlin, the Institute for Cultural Inquiry (ICI, Berlin), and the graduate school "Media of History - History of Media" (Weimar/Erfurt/Jena). His forthcoming book deals with the intersections between media, law, psychiatry, and literature, especially concerning cases of troublemakers, quarrelers and vexatious litigation. Further research and teaching interests include media theory, media history and media philology.

Books: Querulieren. Streit, Wahnsinn und Lärm 1700-2000 (forthcoming 2019).

More Information: http://staff.germanistik.rub.de/gaderer/ 